\title{
Study on Efficiency of FMCG Industry
}

\author{
Cai-fen Zou \\ School of Accounting, Wuhan Textile University,Wuhan,Hubei,China,430073 \\ Email: hicarol@163.com
}

\begin{abstract}
FMCG industries make profit and realize the value through the scale operation featured with high frequent and repeated consumption. It is one of the important industries that influence the economic development. In China, the famous FMCG enterprises such as Nestle, Pepsi cola, Coca Cola, Starbucks, Johnson \& Johnson, $P \& G$, are all multinational companies, while domestic Chinese companies capture a far lower market shares than those transnational Giants. The paper uses a method of DEA to make an empirical research on the efficiency of FMCG public companies. Through the optimization analysis of the input and output, the paper explores the current development of China's FMCG industries and finds problems and advantages of each decision unit in DEA, furthermore, the paper propose some suggestions on how to improve the FMCG industries, encourages the enterprise management to value the actual operating capacity more scientifically and objectively, and hence to enhance the competitiveness of local Chinese companies in the industry of FMCG.
\end{abstract}

Index Terms - FMCG; DEA model; Efficiency; Competitiveness

Fast Moving Consumer Goods (FMCG) are the consumer goods with short service life and rapid pace of consumption. The reasons why they are called fast moving are because they are the daily necessities which rely on consumer high frequent and repeated consuming, therefore FMCG industries make profits and realize the value through scale operating. FMCG involves a wide range of our everyday life, food, beverages, tobacco and alcohol, skin care, hair care, personal care products, detergents, paper products, cosmetics, baby products and so on. The FMCG is different from household appliances, furniture and other durable goods, since the purchase decisions and the purchase process are obviously different. FMCG are the impulse purchase products, spontaneous purchasing decision emphasis on personal preferences. Products' appearance, packaging, promotional advertising and prices have large impact on sales.

The FMCG industry is highly competitive market with relatively rich profit margin and large scaled sales and fast pace of development, and it is an industry which is one of the earliest opening up in China and highest degree of marketization, and it's also an industry filled with various international brands, domestic brands promising the most and the fastest. As one of the important industries in China, The FMCG industry exposes an very important impact on China's economic development. However, the embarrassing fact is that most of the local brands which compete with multinational groups can only occupy the low-end market in most product lines and the foreign brands are firmly in control of the highend market. It can be imagined that when the multinational groups foothold in the Chinese market, in order to maximize profits, they would not hesitate to take a strong infiltrate or a massive attack and capture the market share took by the local brands. This paper used data envelopment analysis (DEA) method, and build enterprise efficiency evaluation model with the sample of the listed companies in FMCG industry and used DEA2.1 software to analyze the efficiency of the samples.

\section{Research Design}

A. Research Methods

This paper used the method of data envelopment analysis(DEA) with the accounting financial index representing the industry characteristics as inputs and outputs index. which is based on the conception of relative efficiency, is a non-parameter statistics method to evaluate whether the same kinds of high input and output of decision units are technological effectively. As the DEA method needn't to estimate parameter in advance, it extends the simple efficiency conception of single input and single output to multi-input and multi-output to analyze the efficiency of production; what's more, it greatly enriched the microeconomics of production function theory and its application technology. It cannot be underestimated that DEA has the advantage of avoiding subjective factors and simplified operations as well as reducing errors. DEA not only can use linear programming to judge whether the decision unit corresponding points are in effective production function, but also can calculate the ideal value of every decision unit indicator by the model, consequently, it can obtain the improvement method of decision unit. What's more, DEA can be used as a performance evaluation method in different enterprises and industries. Therefore, this paper will be based on the public company's efficiency evaluation mode of DEA FMCG industries for further research.

\section{B. The selection of Decision-Making Units}

The paper took the listed companies of FMCG industry in 2009 as samples of the decision units. According to www.cnlist.com, we had 131 FMCG public companies in total by the classification standards of global industries. To ensure the consistency of the data, we exclude B shares; to eliminate the outliers, we exclude ST companies and those companies with incomplete data. And finally the paper obtains 78 samples from the whole public companies. Among which, there are 25 public companies of beverage, accounting for $32.05 \% ; 15$ public companies of agricultural product, accounting for $19.23 \%$; 32 public companies of food, accounting for $41.03 \%$; 6 public companies of commodity, accounting for $7.7 \%$. So we choose a total of 78 decision units in the beverage, agricultural product, food and daily necessities.

C. The Choice of Financial Analysis Index System

The evaluation of enterprise efficiency is a comprehensive analysis to reflect the enterprise's profitability, 
solvency, development ability and operational capability. The input index the paper selected are log of fixed assets, log of intangible assets, log of current assets, log of prime operating costs, log of periodic costs and asset-liability ratio; the output index are prime business profit margin, rate of return on net asset, total assets turnover ratio, inventory turnover ratio, capital accumulation rate, earnings per share. In conclusion, we select 12 input and output index and 78 decision-making units, they are fully satisfied the requirement that the DEA number of decision-making units should be greater than the number of evaluation index. As the decision-making units are from public companies of FMCG industry, so what we select are satisfied the requirement that the sample must belong to the same type of decision-making units.

\section{DEA Analysis of Decision-Making Units}

Since DEA2.1 software input-output index cannot be negative number, the input and output index of decisionmaking units which have negative decision unit will be listed separately. Sum all output index to get a comprehensive output index and analyze the two parts separately, and it can be worked out each output/input index value of 78 sample in 2009 shown as follows.

\section{A. The Efficiency Analysis of Decision Making Units}

Whether a company has reached the scale efficiency can reflect whether the inputs and outputs reach the optimal state, that is, to minimize the production cost, the efficiency optimization can be achieved.

We found that from the overall operation efficiency perspective, 21 of 78 listed companies achieved a DEA efficiency of 1, which accounts for $26.92 \%$ in the listed companies. They are Luzhou Laojiao, Tibet Development, Chengde Lulu, Zhangyu A, Hannan Yedao, Guizhou Moutai,Huiquan Beer, Jinfeng Wine, Guanghong Holdings, Zhenghong Science \& technology, Shuanghui Development, Denghai seed, Tianbang shares, Gaojin food, Zhengbang Science \& Technology, Tianbao Shares, Huazi Industry, Zhongshui Fishery, Ronghua Industry, Sanyuan Shares, Liangmianzhen. The production is at the Pareto best, The comprehensive efficiency value of another $44.87 \%$ companies is above 0.5 and the total efficiency of the rest $28.21 \%$ companies is below 0.5 . Secondly, from the aspect of pure technical efficiency, $48.72 \%$ of sample enterprises have come to 1 in the pure technical efficiency. And the remaining $51.28 \%$ are between 0.5 and 1 . When it comes to the scale efficiency, $33.3 \%$ of the companies reach the scale of 1 , and $43.59 \%$ are just between 0.5 and 1 , while the remaining $76.89 \%$ are below the scale of 0.5 .

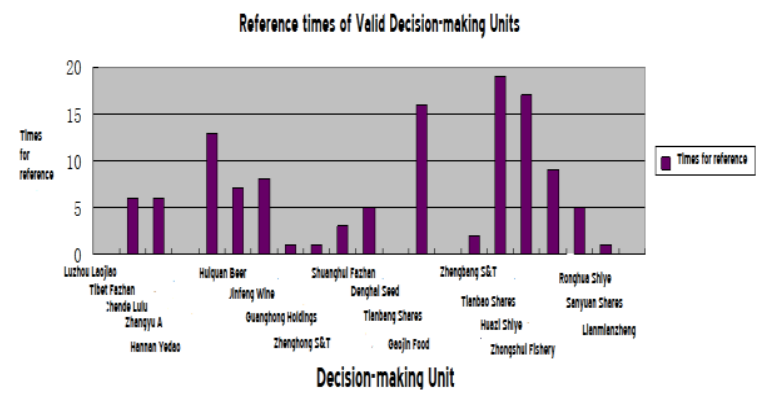

Fig 1. Histgram of Reference times of Valid samples of DEA

For the companies which are DEA efficient, the standard of evaluating their advantages and disadvantages is mainly determined by the referred numbers by other companies. Projection histogram is as aboves.

\section{B. The Classification Ranking of Decision Making Units \\ According to global industry classification standard} (GICS),sample decision-making unit is divided into four major categories as beverages, agricultural products, food and daily necessities. Taking the total efficiency as the main evaluation standard, combined with the number of each referred by other companies to determine their advantages and disadvantages, the decision-making unit classification ranking hence produced.

\section{1) Beverages}

Among the 24 enterprises in decision-making unit of beverages, there are eight companies reached a total efficiency of 1, Hainan Yedao is ranking first, its prime business is the brewery, inputs and outputs is optimal. In addition, there are $41.67 \%$ companies in the $0.5-1$, there are still $25 \%$ of the companys total operating efficiency is below 0.5 , the efficiency of these companies needs to improve.

TABLE 1 Ranking of Decision-making units of Beverage Industry

\begin{tabular}{|c|c|c|c|c|c|}
\hline Ranking & Company name & Overall fficiency & Ranking & Company name & Overall fficiency \\
\hline 1 & Hainan Yedao & 1 & 13 & Jinzhongzi Wine & 0.747 \\
\hline 2 & Huiquan Beer & 1 & 14 & ShenshenbaoA & 0.638 \\
\hline 3 & Guizhou moutai & 1 & 15 & Jiugui Wine & 0.616 \\
\hline 4 & Tibet Development & 1 & 16 & Laobaigan wine & 0.579 \\
\hline 5 & Chengde Lulu & 1 & 17 & Lanzhou Huanghe & 0.517 \\
\hline 6 & Jinfeng Wine & 1 & 18 & Chongqing Beer & 0.504 \\
\hline 7 & Luzhou Fajiao & 1 & 19 & GuYue LongShan & 0.443 \\
\hline 8 & Zhangyu A & 1 & 20 & Pijiuhua & 0.37 \\
\hline 9 & Wuliangye & 0.883 & 21 & Yanjing beer & 0.319 \\
\hline 10 & Shuijinfang & 0.861 & 22 & Gujing Distillery & 0.318 \\
\hline 11 & Yilite & 0.829 & 23 & Tuopai Liquor & 0.285 \\
\hline 12 & Tsingtao Brewery & 0.814 & 24 & Guotou Zhonglu & 0.207 \\
\hline
\end{tabular}




\section{2) Agricultural Products Industry}

There are 4 companies reached DEA efficient in 12 decision-making units among the agricultural products industry, 5 companies, that is $33.3 \%$ of the agricultural products companies have DEA below 0.5 , which indicated that the overall efficiency of the agricultural products in FMCG industry in China is in a serious inefficient stage from the technology or scale, which needs much improvement.

TABLE 2 Ranking of Decision-making unit of Agricultural Products Industry

\begin{tabular}{|c|c|c|c|c|c|}
\hline Ranking & $\begin{array}{c}\text { Company } \\
\text { name }\end{array}$ & $\begin{array}{c}\text { Overall } \\
\text { efficiency }\end{array}$ & Ranking & $\begin{array}{c}\text { Company } \\
\text { name }\end{array}$ & $\begin{array}{c}\text { Overall } \\
\text { efficiency }\end{array}$ \\
\hline 1 & $\begin{array}{c}\text { Tianbang } \\
\text { Shares }\end{array}$ & 1 & 9 & $\begin{array}{c}\text { Tongwei } \\
\text { Shares }\end{array}$ & 0.741 \\
\hline 2 & $\begin{array}{c}\text { Ronghua } \\
\text { Industry }\end{array}$ & 1 & 10 & $\begin{array}{c}\text { Fengle } \\
\text { Seeds }\end{array}$ & 0.638 \\
\hline 3 & $\begin{array}{c}\text { Zhenghong } \\
\text { S\&T }\end{array}$ & 1 & 11 & $\begin{array}{c}\text { Dunhuang } \\
\text { Seed }\end{array}$ & 0.493 \\
\hline 4 & $\begin{array}{c}\text { Denghai } \\
\text { Seeds }\end{array}$ & 1 & 12 & $\begin{array}{c}\text { Xinsai } \\
\text { Shares }\end{array}$ & 0.489 \\
\hline 5 & $\begin{array}{c}\text { Mogao } \\
\text { Shares }\end{array}$ & 0.894 & 13 & $\begin{array}{c}\text { Xinnong } \\
\text { Kaifa }\end{array}$ & 0.397 \\
\hline 6 & $\begin{array}{c}\text { Tinkang } \\
\text { Biology }\end{array}$ & 0.857 & 14 & $\begin{array}{c}\text { Jinjian } \\
\text { Cereals }\end{array}$ & 0.316 \\
\hline 7 & Xinxiwang & 0.802 & 15 & Beidahuang & 0.218 \\
\hline 8 & $\begin{array}{c}\text { Wanxiang } \\
\text { Delong }\end{array}$ & 0.761 & & & \\
\hline
\end{tabular}

3) Foods Industry

The food is the largest sub-sectors in FMCG industry, its efficiency greatly influenced the development of the public companies of FMCG industry in our country. As can be seen from the table 4 , there 8 companies are in the frontier of efficiency of 32 sample companies that account for $25 \%$, $43.75 \%$ of its total operational efficiency is $0.5-1,31.25 \%$ of the companies is below 0.5. From this we can see that the operational efficiency of the food public companies in our country is not so good.

TABLE 3 Ranking of Decision-making units of Foods Industry

\begin{tabular}{|c|l|c|c|l|c|}
\hline $\begin{array}{c}\text { Ran } \\
\text { king }\end{array}$ & \multicolumn{1}{|c|}{ Company name } & $\begin{array}{c}\text { Overall } \\
\text { efficiency }\end{array}$ & $\begin{array}{c}\text { Ran } \\
\text { king }\end{array}$ & \multicolumn{1}{|c|}{ Company name } & $\begin{array}{c}\text { Overall } \\
\text { efficiency }\end{array}$ \\
\hline 1 & Tianbao Shares & 1 & 17 & Weiwei Shares & 0.68 \\
\hline 2 & Huazi Industry & 1 & 18 & Dongfang Oceans & 0.619 \\
\hline 3 & Zhongshui Fisheries & 1 & 19 & Nanning Sugar & 0.562 \\
\hline 4 & $\begin{array}{l}\text { Shuanghui } \\
\text { Development }\end{array}$ & 1 & 20 & Dajiang Shares & 0.553 \\
\hline 5 & Zhengbang S\&T & 1 & 21 & Luoniushan & 0.534 \\
\hline 6 & Guanghong Holdings & 1 & 22 & Sanquan Foods & 0.514 \\
\hline 7 & Sanyuan Shares & 1 & 23 & Guitang Shares & 0.473 \\
\hline 8 & Gaojin Foods & 1 & 24 & Bright Dairy & 0.437 \\
\hline 9 & Zhangzidao & 0.957 & 25 & Longping Hi-Tech & 0.363 \\
\hline 10 & Fuchen Fufeng & 0.904 & 26 & Dahu Shares & 0.354 \\
\hline 11 & Anqi Yeast & 0.903 & 27 & Haitong Group & 0.315 \\
\hline 12 & Xin Wufeng & 0.879 & 28 & COFCO Tunhe & 0.313 \\
\hline 13 & Haodangjia & 0.859 & 29 & Shunxin Agriculture & 0.288 \\
\hline 14 & Minhe Shares & 0.829 & 30 & Hengshun Vinegar & 0.174 \\
\hline 15 & Shanxi Fenjiu & 0.823 & 31 & Xinzhong Ji & 0.14 \\
\hline 16 & Shanghai Meiling & 0.753 & 32 & Harbin High-Tech & 0.032 \\
\hline
\end{tabular}

\section{4) Daily Necessities}

There are only 6 daily necessities companies in the chosen 78 decision-making units. Among which only 1 of 6 companies reached a total efficiency of 1 and the remaining 5 in decision-making units belonging to the DEA inefficient state.

TABLE 4 Ranking of Decision-making unit of Daily necessities Industry

\begin{tabular}{|c|c|c|c|c|c|}
\hline Ranking & Company name & $\begin{array}{c}\text { Overall } \\
\text { efficiency }\end{array}$ & Ranking & $\begin{array}{c}\text { Company } \\
\text { name }\end{array}$ & $\begin{array}{c}\text { Overall } \\
\text { efficiency }\end{array}$ \\
\hline 1 & LiangmianZheng & 1 & 4 & Rebecca & 0.532 \\
\hline 2 & Guangzhou Langqi & 0.848 & 5 & Sftto & 0.299 \\
\hline 3 & Shanghai Jiahua & 0.812 & 6 & $\begin{array}{c}\text { Nanfeng } \\
\text { Chemical }\end{array}$ & 0.137 \\
\hline
\end{tabular}

\section{Conclusions}

We get some conclusion from this research:

1) The whole efficiency in this area is not ideal. At the same time, A huge difference exist in this area. The average efficiency is 0.4965 . The pure technical efficiency of 0.973 , The average scale efficiency for 0.505.This statistics can reflect about $50.35 \%$ resource is wasted during the production. And owing to the wrong decision from the managers or the sever competition in this area, the waste of resources to total waste of about $49.5 \%$.Due to excessive investment the waste of resources to total waste of about $2.7 \%$

2) 21 companies reached the DEA effective .This number indicate the efficiency is in the frontier of the whole area. 17 companies in the rest of the 58 companies have weak efficient DEA, the reason is invalid in scale. And 41 companies are completely invalid, we can realize the reason through the loosen distribution variables. From this data, We can see the FMCG industry in China market small market share in the international market, and the competitiveness in FMGG is also very weak, because the company's total operation efficiency is 1 only accounts for $26.92 \%$ of the total sample.

3) The whole industry, 20 companies have the total efficiency number is 1.During these company, 8 company belong to drink area, 8 home belong to food, four belong to agricultural products, These data can explain our country's FMCG industry has poor competitiveness, However foreign capital enterprise have a place in the whole international market. And the cosmetics, wash protect supplies and hairdressing hair care products and others in FMCG area have big profits and market potential. Therefore, In order to increase local enterprise's market share, we must improve its efficiency and make a big improvement in the input and output of the FMCG.

Based on the above analysis, we needs to improve our country's FCMG listed company competitive power and the total operation efficiency. In order to enhance the competitiveness of FCMG, We should decide the investment amount according to each company analysis results.

\section{References}

[1] Chen Zhiping. Fast moving consumer goods industry market trends in 2010. Now marketing. 2010.3.

[2] Ding Mingli. Fast moving consumer goods industry bigger and stronger and the risk aversion. The Chinese market. 2008.15. 